\title{
Autologous Lymphoma Cell/Autologous Dendritic Cell Electrofusion Hybrid Vaccine
}

National Cancer Institute

\section{Source}

National Cancer Institute. Autologous Lymphoma Cell/Autologous Dendritic Cell

Electrofusion Hybrid Vaccine. NCI Thesaurus. Code C85450.

A cell-based cancer vaccine consisting of hybrid cells created by electrofusing autologous dendritic cells (DCs) and autologous lymphoma cells with potential immunostimulating and antitumor activities. Upon administration, autologous lymphoma cell/autologous dendritic cell electrofusion hybrid vaccine may stimulate the immune system to mount a specific cytotoxic T-lymphocyte (CTL) response against specific autologous lymphomaassociated antigens, resulting in lymphoma cell apoptosis. 